\title{
Neutral Spaces: The Close Relationship Between Professional and Educational Spaces
}

\author{
Roberta Barban Franceschi, Adolfo Jordán Ramos, Lucinda Morrissey, María Jesús Triviño \\ Universidad Europea de Madrid, Madrid, Spain
}

\begin{abstract}
This article reflects on new educational spaces, which are similar to the work areas of a creative company, spaces that simultaneously stimulate students, professors, visitors, etc. There are flexible spaces that respond to the different needs of all these kinds of users. These spaces are referred to as "neutral spaces" in this article. In European education, the Bologna Plan's implementation has brought the academic context much closer to the professional. This change has required the actors involved to develop skills and competencies that stimulate collaborative working, connectivity, creativity, and an entrepreneurial outlook. Without doubt, it has also brought people closer to the needs of innovative companies and progressively to the need for educational spaces, which are more akin to workspaces. The main focus is placed on the analysis of new educational spaces in universities and the collaboration between university and business, both are principal aspects in the investigation of the Steelcase Chair of Educational Spaces and Facilities. To link design activities within the European University of Madrid BA Design Degree with the company Steelcase, to study the issue of neutral spaces with the intention of providing teaching, that is intended to be closer to the professional environment. The purpose of this research is to verify the spatial needs of the university and compare them to professional spaces. For this a data collection process was created in which company and university spatial circumstances are studied to determine equivalences. From these findings a collaboration between the university and company was developed, involving students and developing a dynamic collaborative work model for all involved.
\end{abstract}

Keywords: neutral spaces, educational spaces, university, creative companies, collaboration between university and companies, learning process

\section{Introduction}

This article makes explicit the ever closer relationship between of the company and university contexts, which is reflected in the spatial architecture. It covers an evolution of the social contexts and their translation to the field of spatial design with a review of the theorists who have studied the subject. The neutral (informal)

Roberta Barban Franceschi, architect, Department of Architectural Design, Graphic Expression, History, Art and Design, Architecture, Engineering and Design School, Universidad Europea de Madrid, Madrid, Spain.

Adolfo Jordán Ramos, architect, Department of Architectural Design, Graphic Expression, History, Art and Design, Architecture, Engineering and Design School, Universidad Europea de Madrid, Madrid, Spain.

Lucinda Morrissey, graphic designer, Department of Architectural Design, Graphic Expression, History, Art and Design, Architecture, Engineering and Design School, Universidad Europea de Madrid, Madrid, Spain.

María Jesús Triviño, architect, Department of Architectural Design, Graphic Expression, History, Art and Design, Architecture, Engineering and Design School, Universidad Europea de Madrid, Madrid, Spain.

Correspondence concerning this article should be addressed to Roberta Barban Franceschi, UEM Urb. El Bosque, Calle Tajo, s/n, 28670 Villaviciosa de Odón, Madrid, Spain. 
business spaces are identified; it without much meaning before, but now gaining in importance and content. University spaces are then revised, where an attempt to recreate the same type of space is identified and reviewed. Finally, the authors reach conclusion with the experience in Universidad Europea.

Universities have been physical institutions ever since they were first created. The first university was founded around the 13th century as space inherited from monastic cloisters, where the Absolute Truth was taught. Much later, due to the increase in student's numbers, their architectural typology evolved in the 1960s into large complexes situated in the suburbs-segregated from cities.

Today the university as a "City of Knowledge" is no longer strictly a physical space due to the advances in technology. A non-physical information-based site was created to take its place, namely, the virtual campus. Doubts exist with regards to this digital concept, since it rivals the university's traditional mission of educating students through direct contact and physical presence.

Technology has allowed today's society to no longer be subject to either space or time. In principle, it has freed us of many obligations, but at the same time, it has also invaded people's lives and its presence occupies much time. Leading to a new development of social structures that could be called "informationalism" (Castells, 1996), where the concept of Temporary and Physical Space fades, only the Ontological Space remains, especially with the new online possibilities as noted by Augé (2005).

The world is becoming increasingly intellectual. Cerebral and virtual activities prevail over manual activities, not only during periods of work but also during leisure time. Among intellectual activities, creativity is the most highly valued and has become an essential value for today's society. The stimulus provided by creativity is vital for human beings. De Masi (2000) explained the way in which creative groups have exerted an influence on all areas of human knowledge from the industrial revolution to the present day.

Today the work spaces of innovative companies are designed by, and for, creative people, a large number of whom belong to the Generation Y (Matute, 2007). People who have grown up surrounded by technology take decisions in real time and demand immediate responses and results.

The extraordinary volatility and flexibility of information are ways of thinking and living, which mean that there is a permanent transformation in today's society; a liquid society that is always in a state of flux. The most illustrative example of this idea would be the fashion industry with its continuously changing trends, reflecting a volatile and fluid collective (Bauman, 2007).

In the early 20th century, the "Taylorist" work character prevailed. The first office copied the structure seen in factories, repeating the dynamics of the production line (Myerson, Bichard, \& Erlich, 2010). This model was then reflected in the areas of education, with the arrangement of tables in rows with the teacher being the center of attention with a panoptic view of the complete classroom.

In addition, Florida (2010), an expert in demographic and urban trends, economic competitiveness, and technological innovation, complemented Bauman's theory of "liquid society" (Bauman, 2007) with what he called a "creative society" and their working relationships, understanding human creativity as the driving force of change is the key factor to economic prosperity for society (Florida, 2010).

These spaces apply a design philosophy that constitutes a radical break with the Fordist styles of work, which viewed workers as passive, linear, and isolated from others; they are similar to the notion of a production chain, where socializing did not take place. In the model now in use by these innovative companies, workers are seen as fluid, mobile, and connected assets. They are physically integrated into society through spaces, which stimulate collaboration, debate, and dialogue, as well as through virtual spaces like Dropbox, Google 
Drive, or Facebook, among others. One can already see examples of some universities adopting these concepts for their communal areas.

De Masi (2000) explained the fact that creative people need emotion, fantasy, and illusion, he justifies that emotion is an essential ingredient for creation. From his viewpoint, a creative person should be a hybrid of reason and emotion. Rationality was a characteristic developed in an industrial society, which allowed people to materialize ideas and put them into practice. Emotion is the new characteristic that should be encouraged today.

In the socio-cultural consequences of informational development, psychology and sociology have analyzed thoroughly the behavior of the main current generation in both the academic and professional circles during this period of informational development, establishing a classification of three generations divided by birth, who cohabit but have very different profiles. The Generation X, those born in the 60s and 70s, is made up of individuals who are very skeptical in politics (as a result of repression and experienced frustration with the previous generation), and go against the values characterized by their parents, offering a radically different social model, according to a report by the Spanish business school Escuela de Negocios Instituto de Empresa and Adecco (Gil \& Morales, 2009). They appreciate flexibility at work, and feel less material attachment than previous generations seeking employment stability, who remained 20 or 30 years in the same company, as explained by Filho (2010).

The Generation $\mathrm{Y}$ is made up of younger professionals currently in a constant pursuit of creativity and flexibility. They have qualified training, but refuse to live for work and demand from employers for better working hours, salary, and a professional career. They hate endless workdays because they want to control their time and not miss out on other activities that interest them, they reject jobs requiring high sacrifice or excessive commitment and enjoy change. In Matute's (2007) article on the Generation Y, she identified some important features: "Generation Y perform better in a creative environment where independent thinking is valued", adding "they want committed and fair leaders and tend to question the status quo. It is important always to tell them the truth. In order to enlist their support, one should explain each decision and remind them of the benefits" (Matute, 2007). Within the context of current students, the Generation Z, born with all the information technologies at their disposal: mobile phone, internet, game consoles, and MP3, is the generation of social networks and they are connected every minute of the day. They represent a group with knowledge of advanced digital technology and socialize within the special dynamics of social networks. They are individuals of their times, they manage information well, they are immersed in all kinds of events and virtual relationships and attend university equipped with all kinds of accessories that link them to the cyberspace, but often this huge amount available media makes them inactive and impatient with a configured link with the immediate context. They are students, who sometimes are unable to proceed in a reflexive manner required for quality personal construction and are unlikely to be receptive, patient, or constant.

In European education, the Bologna Plan's implementation has brought the academic context much closer to the professional. This change has required the actors involved to develop skills and competencies that stimulate collaborative working, connectivity, creativity, and an entrepreneurial outlook. Without doubt, it has also brought people closer to the needs of innovative companies and progressively to the need for educational spaces, which are more akin to workspaces.

Universities will have to place the limelight on spaces that encourage coexistence, meetings, and collaboration, where the dynamics and the way of working are no longer the same as in traditional classrooms, with continuous learning dynamics within and beyond the classroom. 
This article reflects on new educational spaces, which are similar to the work areas of a creative company, spaces that simultaneously stimulate students, professors, visitors, etc. There are flexible spaces that respond to the different needs of all these kinds of users. These spaces are referred to as "neutral spaces" in this article.

\section{Neutral Spaces}

The design of technology company offices or co-working spaces has to be configured today in a way that encourages open and closed spaces, concentrated work rooms or working in teams, along with informal communication or rest areas. Exchange networks allow the creativity to flow and socialize with others to arise, with which the user feels free and at ease. Emotion is thus linked to the most human experience of space and design. A space focused on the individual is created, a more human space that fosters wellbeing. A connected network in which the user, at all times, chooses the kind of space that best fits with their needs.

Informationalism, according to Castells (1996), is a technological paradigm. It concerns technology, not social organization or institutions. Informationalism provides the basis for a certain type of social structure that Castells (1996) called the "network society". Without informationalism, the network society could not exist, but this new social structure is not a product of informationalism, it is a broader pattern of social evolution.

The difference between professional spaces and educational spaces has been diminishing over the years. Today, there are without doubt some very strong links between both kinds of environment and it is becoming increasingly difficult to set the limits which separate them. The evolution of society and the new requirements in these areas have gradually led to an increasing similarity. Today, learning and putting this into practice is a continuous process that is also reflected in the spatial design. In general terms, the greatest innovations arisen in business environments give that companies are opting for less conventional solutions that favour productivity, in addition to energy and cost savings.

Projects like office designs for Pixar (Emeryville, California, USA), Facebook (Palo Alto, California, USA), and Google (Zurich, Switzerland) apply these concepts. In these spaces, one can see that emotional and rational components intermingle, so workers may make use of the spaces depending on their current needs: spaces for teamwork, individual work, or leisure. Diversity in space typologies is encouraged in these new offices, thereby boosting collaboration and flexibility.

In the university, spaces that fulfil this function are called neutral spaces. Based on the document (Braidy, 2013) entitled "Guía de criterios de diseño para los espacios administrativos de la UNED" (Design Criteria Guidelines for UNED Administrative Spaces), this research Chair proposes four concepts to be used in the so-called "neutral spaces" of the university:

(1) Closed collaboration spaces for small meetings or activities like workshops or small lectures;

(2) Open collaboration spaces for informal meetings, concentrated work, teamwork, etc.;

(3) Emotional creative spaces, rest areas, informal meeting, and communication areas with low tables and armchairs;

(4) Concentration spaces, a silent ambiance free from distractions that allows one to work occasionally in a closed room for individual concentrated work.

\section{Universities}

The main focus is placed on university campuses. Today, such an environment needs a variety of different spaces and an ideal scenario to replicate the atmospheres which characterize the professional world. The goals 
sought are those which configure universities as a space for research, collaboration, and innovation, in addition to improving the quality of the university system. The new demands placed by the European Higher Education Area (EHEA) require the modernization of European universities.

As opposed to traditional work and study spaces, where each space is destined to a specific purpose, the new spaces are flexible and adaptable and offer a wide variety of activities. There is no delimited individual space for each student or worker. Rather, collaboration is sought among people in communal areas equipped with the necessary tools for cognitive interchange.

A variety of factors have contributed to this transformation, such as the sustainability, cost savings, demographics, globalization, technology, and changes in society.

The need for a physical communal space is something that is also deemed essential by Alexandra den Heijer, an architect and professor at the Delft University of Technology in the Netherlands. The notion of a campus within the city is present in the refurbishment of BK City, the university's School of Architecture. University spaces are integrated into those of the city, so that students and residents alike can make use of the services and amenities at any time. Meeting areas like cafeterias or libraries, activities, lectures, etc. foster this interchange. The city provides services to the university, as does the university to the city. Consequently, the learning environment becomes the third teacher.

Another significant university-driven initiative is that of the University of Brighton in the United Kingdom. It explores the creative possibilities of spaces that can be adapted to any activity or educational need. The Creativity Centre is comprised of two halls (Leonardo and Galileo), which are equipped with basic furniture, walls, mobile separators, temperature and lighting controls, olfactory control system, audio visual equipment (projectors, cameras, etc.), and games like Lego or Connect Four. The halls are fully adaptable to the kinds of activities carried out there, ranging from training sessions or courses to dance classes or theatre. This represents a new typology of flexible space.

The hub is located within Coventry University. It is a space for students in their free time between classes, which was created to cater for student's needs of comfort in an informal learning space that stimulates collaboration. It can hold up to 1,000 students at one time. These workspaces are being implemented at universities to meet student's needs, their proximity to the professional world and layout of a working environment is clear, and there is an ever increasing number in European universities.

\section{University and Company Cooperation}

These types of research chairs encourage entrepreneurship among academics by developing lines of investigation that are related (Larrauri \& Clemente, 2000) and also to companies if they share this interest in knowledge development, and use of new teaching methodologies and space requirements.

The collaboration activity between university and business was made possible by the fourth year of the BA Interior Design Degree students in the subject "Surveys and budgets. Direction and production. Standards" during the 2014/2015 academic year, taught by the professors Adolfo Jordán and María Jesús Triviño.

The proposal to design a neutral space was incorporated to the subject as a project intended to apply the theoretical knowledge acquired in their studies, in addition to the recent realities identified during the investigation. Thus prepare students for an immersion in working life and enhance the development of interdisciplinary skills such as time management, communication, responsibility, self-confidence, and other specific skills related to the profession. 
The problem presented to the students proposed an interior design project within the Universidad Europea Madrid (UEM) Campus—in Villaviciosa de Odón—specifically in the B Building's neutral spaces; identified as the first, the second and the third floor are hall lobbies and cafeteria. In these renovated spaces, the users would be able to perform various activities, such as collaborative meetings, tutorials, both individual and team study, as well as rest and eat. The students were required to incorporate to their project the Steelcase furniture designed for such spaces.

Six projects were developed and three were selected to be presented to Steelcase (Figures 1, 2, and 3).

The dynamics of the experience (among professionals, professors from various areas, and students) reflects the previously mentioned concepts, in the field of design, of "interdisciplinary" and "multidisciplinary"-in the field of design, not a mere proclamation but a reality. The interdisciplinary project undertaken faithfully reflects the daily reality of the profession. Interdisciplinary design is a fact: the distance between creativity and applied design to a market product is shrinking. All members of the team (students, professors, and collaborators) became the professionals in this exercise, leaving behind the established roles of training and teaching, organizational hierarchies, and privileged positions. Continued collaboration and a common goal in a flexible and tolerant manner ensured true teamwork, a more professional and less academic part emerged, relegating teaching procedures to professional judgment.

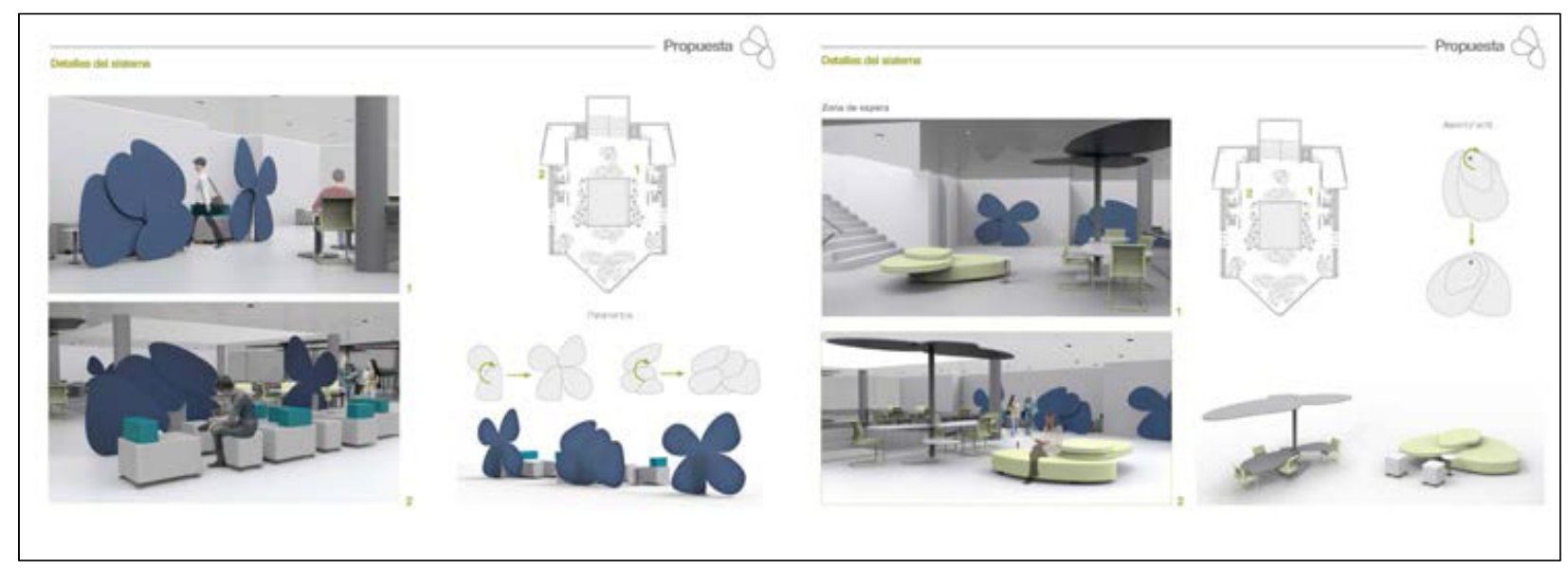

Figure 1. Abla Loudghiri. Neutral spaces project in B Building of the UEM.

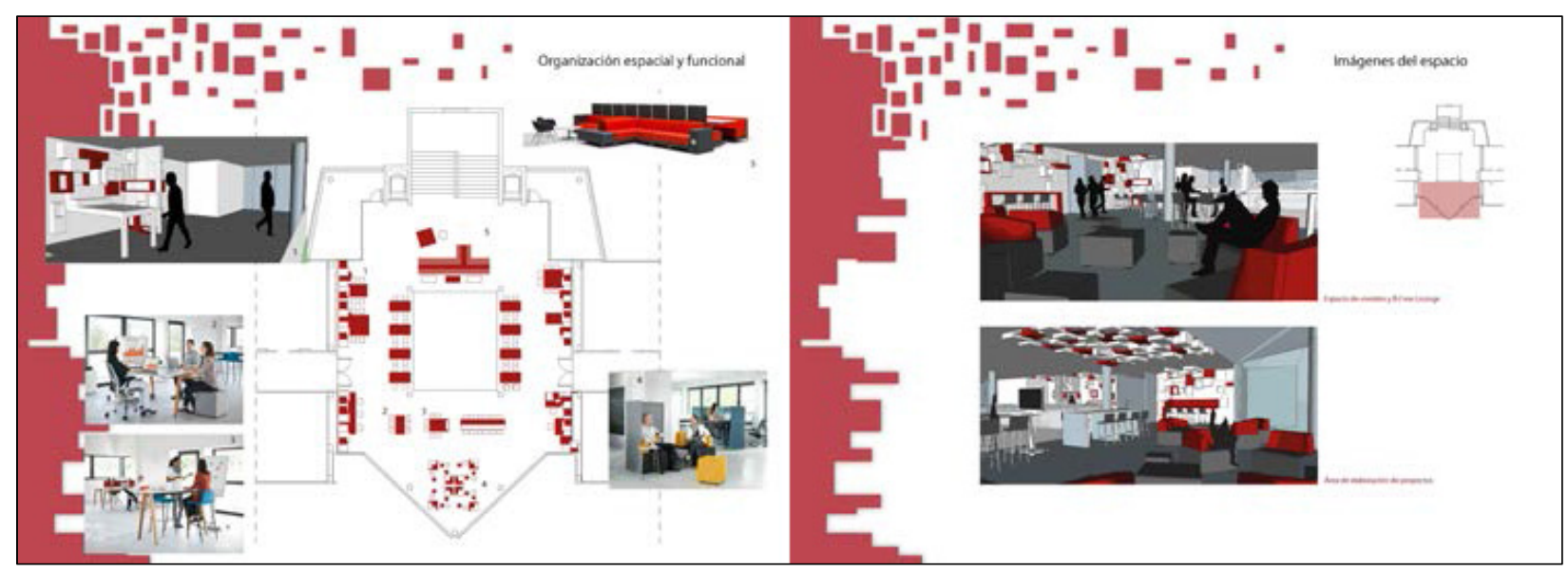

Figure 2. Raquel Díaz. Neutral spaces project in B Building of the UEM. 


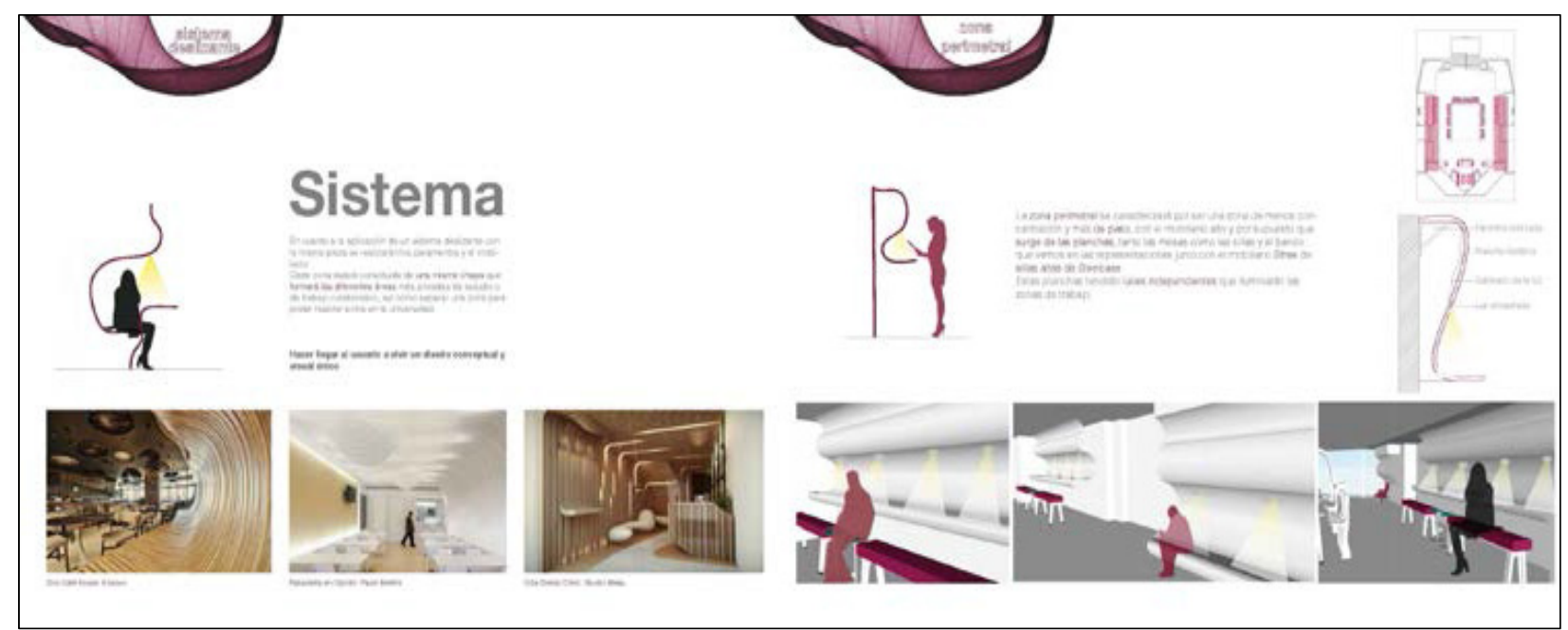

Figure 3. Miriam Múñiz. Neutral spaces project in B Building of the UEM.

\section{Conclusions}

The constant changes undergone by society lead one to propose simple and diverse spaces (flexible and customizable) that can be adapted to each person's needs. In conceptual terms, tablets are a good example of a device that adapts to the needs of a changing society. The experience of uniting university and business has led to an evident break with the traditional classroom space as the absolute protagonist of learning and requires expansion into other areas, transforming the new environments into living mutable elements, where exchanges and contributions of the diverse actors involved are constant.

There are therefore enough indications to firmly believe that business and educational spaces have a common future geared to flexibility. Professional environments require collaboration among employees and the introduction of more efficient, creative, and environmentally responsible work models. Spaces therefore have to be in keeping with these demands. For their part, educational spaces are becoming increasingly like professional models. They must therefore also adapt to their environment. Today's students have changed. They work and study at the same time, or stop working to go back to university. They are more mature and demand professional spaces in the university. This evolution is aimed at increasing the productivity of companies to better prepare students when joining the labour market.

When seeking a learning space that satisfies the needs of contemporary society, it is therefore necessary to attain a new balance, understood as harmony between opposing ideas: technological and analogue, complex and simple, global and local, static and dynamic, physical and virtual, etc. Balance has been a transversal value throughout history. Present times-in the very midst of a digital and social revolution-requires more balance than ever.

Unfortunately, one has as yet to see in the university campus spaces that respond to the needs of students who will be the professionals of the future, there exist few examples of projects and spaces in an academic environment of interest, much more needs to be done in order to turn this context into a reality.

\section{References}

Augé, M. (2005). Los “no lugares”, espacios del anonimato: Una antropología de la sobremodernidad. Barcelona: Gedisa. Bauman, Z. (2007). Los retos de la educación en la modernidad líquida. Barcelona: Gedisa. 
Braidy, C. (2013). Guía de criterios de diseño para los espacios administrativos de la UNED. Retrieved from http://portal.uned.es/pls/portal/docs/PAGE/UNED_MAIN/LAUNIVERSIDAD/VICERRECTORADOS/EVALUACIONCA LIDAD/IN FRAESTRUCTURA/06-GUIA\%20DE\%20CRITERIOS\%20DE\%20DISEÑO_251010.PDF

Castells, M. (1996). La sociedad red. volumen 1 de La era de la información: Economía, sociedad y cultura. Madrid: Alianza Editorial.

Filho, A. T. (2010). Geração Y, Geração Xe Baby boomers: Sinergia ou cisão em projetos? Recuperado 10 de Septiembre de 2012. Retrieved from http://www.metaanalise.com.br/inteligenciademercado/index.php?option=com_content \&view=article\&id=4241:geracao-y-geracao-x-e-baby-boomers-sinergia-ou-cisao-em-projetos\&catid=1:ponto-devista\&Itemi $\mathrm{d}=353$

Florida, R. L. (2010). La clase creativa. La transformación de la cultura del trabajo y el ocio en el siglo XXI. Barcelona: Paidós.

Gil, I., \& Morales, D. (2009). Informe de responsabilidad social corporativa adecco España 2009. Retrieved from http://www.fundacionadecco.es/_data/SalaPrensa/Memorias/Pdf/9.pdf

De Masi, D. (2000). O ócio criativo. São Paulo: Sextante.

Larrauri, J. O., \& Clemente, G. I. (2000). Iniciativas y experiencias europeas en la configuración de espacios regionales de colaboración Universidad-empresa. Revista de Estudios Regionales, 58, 209-226.

Matute, M. (2007). La revolución laboral de la generación Y. Retrieved from http://www.cincodias.com/articulo/sentidos/revolucion-laboral-generacion/20070521cdscdicst_1/

Myerson, J., Bichard, J. A., \& Erlich, A. (2010). New demographics, new workspace: Office design for the changing workforce. Gower Publishing Company. 